\title{
THE SOCIO-CULTURAL ENVIRONMENT, PARENTAL PERCEPTION, ADOLESCENT KNOWLEDGE, AND ATTITUDE TOWARD EARLY-AGE MARRIAGE DECISION
}

\author{
Nona Intan Permatasari Wadjaudje ${ }^{1}$, Nisaul Habibah ${ }^{1}$, Laili Rahayuwati1, Tetti Solehati ${ }^{1}$ \\ ${ }^{1}$ Faculty of Nursing, Universitas Padjadjaran \\ Corresponding email: tetti.solehati@unpad.ac.id
}

\begin{abstract}
The relatively high number of early-age marriages in Indonesia, committed by 60.000 couples under 18 in West Java, even rises from 53 to 117 in 2015 . The socio-cultural environment and parents are the most influential factor in early-age marriages, particularly in villages. However, limited studies determine the social influence on young women decision including deciding early marriage. The research objectives were to identify the sociocultural environment and parental perception toward early marriage decision, and describing how adolescent knowledge and attitude toward early-age marriages. The research design is cross sectional study. The sample is taken using proportionate cluster random sampling, consisting of 144 parents, and 250 adolescents. The result shows that the socio-cultural environment (47.2\%), and parental perception (62.4\%), low level of knowledge (44\%) and positive attitude (52.4\%) to postpone early-age marriage. It can be concluded that the strength of cultural value plays a vital role in the population's health decision. Therefore, it is necessary to develop a program between the government and the healthcare community to overcome early-age marriage issues.
\end{abstract}

Keywords: Adolescent knowledge, attitude, parental perception.

\section{INTRODUCTION}

Indonesia places the second-highest rank of early-age marriage in ASEAN, right after Cambodia (UNDESA, 2011). There, marriage is generally committed by teenagers from 15 to 19 years old as much as $46 \%, 5 \%$ of whom are only under 15 years (BKKBN, 2012). Specifically, the West Java province places the second-highest percentage on early-age marriage under $15(7.5 \%)$.

The number of early-age marriage in Bandung District is currently relatively high from around 600.000 productive couples, $10 \%$ of whom or 60.000 couples get married under 18 (BPS and UNICEF, 2011). Early-age marriages in Bandung District are mostly committed by women as much as $86.06 \%$ and men $41.41 \%$. Some of the triggering factors according to Astuty (2013) include that of economy, family, education, and culture. The parent's low economic status creates discomfort for their children's future in terms of matchmaking. Therefore, it is no surprise that early-age marriage happens in villages with relatively low economic status. However, parents hold a vital role to communicatively influence their children to prepare for future marriage as to achieve prosperous relationship in the family (Talcott Parson in Raho, 2007). Early-age marriage also passes down complex impact to the concerned teenagers, particularly when seen from such aspects as psychology, education, population, and health (BKKBN, 2012). 
The impact, from the health perspective, miscarriages due to the vaginal deficiency that would increase Infant Mortality Rate (IMR). The increase of the rate occurs in West Java from 3979 in 2014 to 4124 in 2015 . On the other hand, Maternal Mortality Rate in 2014 rockets as much as 748 to 824 in 2015 (Ministry of Health, 2015). This happens because early-age marriage passes down bigger risks when committed by female teenagers compared to male. Nasrullah et.al. (2014) argues that, in Pakistan, the impact also involves abuse to married female teenagers under 18. In 2016, 28 cases of divorce from 117 marriages were recorded due to early-age marriage. This happens because they are not ready to have a family and raise future children (Park, 2010).

Socio-culturally speaking, Indonesian parents play vital roles in the family as each will have their take on early-age marriage. Most of them, particularly in villages, consider that it is a positive tradition, and an only small part of the rest would think otherwise. It is important, therefore, to identify their behaviors toward the idea of wedding their children at an early age. The cultural environment is a realistic matter comprising what is considered good or bad, right or wrong, as an abstraction or viewpoint. Hudelsen (2004) puts forward that someone acts based on values that he believes perform repeatedly, and becomes his life guidance.

Parental perception can be used to see the big picture of the prevention program necessary to overcome early-age marriages. Prevention is an activity executed both directly and indirectly to avoid something from health problems or diseases. Parents are also charged with having trustworthy knowledge because either positive and negative parental perception must be based on broad insight which will implicate the susceptibility of health problems. However, limited studies determine the social influence on young women decision including deciding early marriage.

\section{METHODS}

The research method applies the cross-sectional descriptive study with such variables as socio-cultural environment, parental perception on early-age marriage, adolescent knowledge and attitude toward early-age marriage. The population of this research involves 144 parents and 250 adolescents. The sampling method applies the proportionate cluster random sampling technique. Content validity testing and construct is done using Alpha Cronbach, with the variable result testing are 0.13 up to 0.73 with $r$ table of 0.3610 and reliability testing result 0.811 . Data analysis is descriptive and narrative to explain the research variables. 


\section{RESULTS}

The demographic characteristic of respondents will be shown in Table 1.

Table 1 Demographic Characteristic of Parents $(n=144)$

\begin{tabular}{|c|c|c|c|}
\hline \multirow{2}{*}{\multicolumn{4}{|c|}{$\begin{array}{l}\text { Variable } \\
\text { Gender }\end{array}$}} \\
\hline & & & \\
\hline - & Female & 50 & 34.7 \\
\hline- & Male & 94 & 65.3 \\
\hline \multicolumn{4}{|l|}{ Age } \\
\hline - & $18-40$ & 61 & 42.4 \\
\hline - & $41-60$ & 80 & 55.6 \\
\hline - & $>60$ & 3 & 2.1 \\
\hline \multicolumn{4}{|c|}{ Ethnicity } \\
\hline & Sundanese & 144 & 100 \\
\hline \multicolumn{4}{|c|}{ Religion } \\
\hline & Muslim & 144 & 100 \\
\hline \multicolumn{4}{|c|}{ Education } \\
\hline - & Primary School & 97 & 67.4 \\
\hline - & Secondary School & 31 & 21.5 \\
\hline - & High School & 15 & 10.4 \\
\hline - & Diploma & 1 & 0.7 \\
\hline \multicolumn{4}{|c|}{ Family income (rupiah) } \\
\hline - & $\leq 2.000 .000$ & 128 & 88.9 \\
\hline - & $>2.000 .000$ & 16 & 11.1 \\
\hline \multicolumn{4}{|c|}{ Occupation } \\
\hline & Housewife & 84 & 53.8 \\
\hline - & Peasant & 46 & 31.9 \\
\hline - & Breeder & 2 & 1.4 \\
\hline - & Private business & 2 & 1.4 \\
\hline - & Government & 1 & 0.7 \\
\hline & Employee & & \\
\hline- & Non-Government & 9 & 6.3 \\
\hline Tota & & 144 & 100 \\
\hline
\end{tabular}

Based on Table 1, it was found that from 144 respondents found that $(65.3 \%)$ of respondents were female with the most parents in the 41-60 years age range with percentage $(55.6 \%)$ and $(100 \%)$ of respondents were Muslim. Most recent parent education is a primary graduate (67.4\%). For family income $(88.9 \%)$ less than Rp. 2,000,000 per month.

Table 2 Demographic Characteristic of Teenagers $(n=250)$

\begin{tabular}{lcc}
\hline Variable & Frequency & Percentage \\
\hline Age & & \\
12-15 years age & 249 & $99,6 \%$ \\
$15-18$ years age & 1 & $0,4 \%$ \\
\hline
\end{tabular}




\begin{tabular}{lcl}
\hline Gender & 148 & \\
Female & 102 & $49,2 \%$ \\
Male & & $40,8 \%$ \\
Religion & 250 & $100 \%$ \\
Muslim & & \\
Source information & 55 & $22 \%$ \\
Television & 34 & $13,6 \%$ \\
Parents & 25 & $10 \%$ \\
Internet & 15 & $6 \%$ \\
Friends & 11 & $4,4 \%$ \\
Teachers & 1 & $0,4 \%$ \\
Health workers & 109 & $43,6 \%$ \\
Never & $\mathbf{2 5 0}$ & $\mathbf{1 0 0 \%}$ \\
\hline Total & &
\end{tabular}

Based on Table 2 it is found that almost all respondents age (99.6\%) are in the early adolescent stage (12-15 years old) and few of the respondents are in middle adolescence stage (15-18 years) that is (0, $4 \%$ ). Based on the gender of 250 respondents research, most of the respondents are women that is as much $(59,2 \%)$. The religion of all respondents embraced Islam religion. Based on the experience of information that can be some respondents $(43.6 \%)$ never get information about early marriage. Early marriage information sources gained the most from television (22\%), then parents (13.6\%), internet $(10 \%)$, friends $(6 \%)$, teachers $(4.4 \%)$, and health workers $(0.4 \%)$.

Further, the result of the research shows that the socio-cultural environment values from half of the respondents (52.8\%) are supportive of early-age marriage while $47.2 \%$ others are against it. On the other hand, most of the respondents (42\%) remain to think that marriage after high school is local culture, while $41 \%$ others think that women should not pursue higher learning knowing that they will end up in the kitchen. In this case, the researcher assumes, therefore, that early-age marriage has nothing to do with socio-cultural aspects, economic status, nor gender differences. In fact, it is not uncommon that a person decides to quit school due to financial crisis and gets married instead to fulfill his daily needs. Moreover, the number of parents who support early-age marriage is $88(61.11 \%)$, while 56 others $(38.89 \%)$ are against it.

Other results show, $44 \%$ of adolescents have lower knowledge of early marriage. Further, $80 \%$ of adolescents state that one of the factors that cause early-age marriage is simply mutual affection. None the less, $44 \%$ more even have no idea how to prevent the early-age marriage. The result of attitude shows that $52.4 \%$ of the respondents are against early-age marriage, indicating that negative perception toward early-age marriage exists in nearly half of the respondents, contradictory to $47.6 \%$ others. 


\section{DISCUSSION}

The role of gender, depending on the cultural dimension in society. Most women are taught to get married as early as possible to respect tradition and that their ultimate role is to take care of their family. This discourages them to pursue higher learning or education at any level. Livia, et.al. (2014), on the other hand, emphasizes that women's role remains peripheral compared to that of men. Besides, the result shows that culture often becomes a cop-out to cover financial issues, one of which is wedding children at a relatively young age to take off their parents from the burden. This is emphasized by Rumble, et.al (2014) arguing that low economic status becomes the reason to get married and get over with family economic issues.

Parents supporting early-age marriage are taught by well-established tradition and low economic status, hence forcing them to wed their children. Referring to the Health Belief Model in Glanz et.al. (2008) argue that the supporting perception toward early-age marriage tends to display early-age marriage behavior. The perception may influence parents understanding of health to family and implies to health behavior choices. Those who are against it tend to avoid any possibilities potential to damage their children health as a cause of early-age marriage and the high maternal of infant mortality rate. They would discourage, even forbade, their children to marry early. These perceptions come from, indeed, different perspectives, two of which include experience and knowledge.

Glanz (2008) claim that someone will do health behavior based on his presentiment about health itself. The feeling of anxious or threatened derives from a perception that an individual is susceptible to health problems with serious consequence. This research highlights that perceived seriousness is impactful and problematic if a child is wed at such an early age. This will lead to illness, physical and mental deficiency, disability, and social gap. Nasrullah et.al. (2014) explains that the impact is that the female teenager married under 18 encounters domestic abuse as much as $31.8 \%$. If anything, younger women are twice as likely to be at risk than adult women in terms of susceptibility level.

The researcher believes, however, that often do obstacles occur when it comes to performing healthrelated positive behaviors. As Pender (2001) claims that, along with great obstacles, most parents tend to disagree with the idea of wedding their children at an early age. Rosenstock in Glanz et.al. (2008) argues that no matter how demanding the obstacles are, the number of advantages must be much more than the disadvantages. This research, therefore, shows that the highest percentage lies in the advantages $(57.64 \%)$ - that is, parents who are against early age marriage. This means that parents are 
capable of perceiving advantages quite well and understanding what actions to take for the sake of their family. Whether the advantage is supportive must be based on the questionnaire responses. Most of the parents are against early-age marriage and don't think that it gives an advantage in terms of their children fertility.

Although parents know how important it is to marry above 21, reality shows the total opposite. This is shown during a seminar regarding the age of marriage. Some parents, except local authorities, choose to detach from the activity, which exempts other members of the community to participate. This then creates misdirected information for the family's whole prosperity (Field, Erica, Ambruse, 2014).

This is linear with previous research by Montazeri (2016) that someone's motif to come to healthcare service is affected not only by distance but also by transportation availability and affordability. This means that when parents don't participate, they think they are only wasting time. However, coming to the village office, sitting down, and listening to the lecture for a relatively long time are considered boring by many; they would rather do some chores. Above all, the parents assume that such activities will give a positive influence on families with adult daughters while hoping that the idea of wedding their children at an early age will diminish.

The result shows adolescents are not knowing the potential risks, and they support early-age marriage and tend to marry at such an early age. This is also supported by negative perception toward the importance of health education to prevent risk for early-married children.

\section{CONCLUSION}

Cultural environment and parental perception support early-age marriage. These two variables determine the early-age marriage phenomenon compared to pubescent knowledge and behavior toward early-age marriage. Regardless of the age limit and policies that might lower the rate of early age marriage, another important thing is to provide more education for parents, recreational spaces, and educational seminars to adolescents. Equally important is to enforce the law of marriage age limit by, out of many others, strengthening the bureaucracy system on marriage administration and birth certificates. This way, the system will provide age transparency, then early age marriage can be identified and, if possible in any way, prevented.

\section{ACKNOWLEDGMENTS}


This study supported by Ministry of Research, Technology and Higher Education; and National Population Board, Indonesia (BKKBN).

\section{REFERENCES}

United Nations Department of Economic and Social Affairs, (2011).Population Division..

BKKBN. (2012). Provinsi di Indonesia: Akar Masalah \& Direktorat Analisis Dampak Kependudukan Badan Kependudukan Keluarga Berencana.

Unicef. (2011). Early Marriage: Statistic Exploration. Unicef Fund.

Astuty, S. Y. (2013). Faktor-Faktor Penyebab Terjadinya Perkawinan Usia Muda Dikalangan Remaja Di Desa Tembung Kecamatan Percut Sei Tuan Kabupaten Deli Serdang. Jurnal Universitas Sumatera Utara, 2(1).

Raho, B. (2007). Teori Sosiologi Modern. Jakarta: Prestasi Pustaka.

BKKBN. (2012). Provinsi di Indonesia: Akar Masalah \& Direktorat Analisis Dampak Kependudukan Badan Kependudukan Keluarga Berencana.

Depkes. (2015). Infodatin. from Kementerian Kesehatan RI Pusat Data dan Informasi: http://www.depkes.go.id/resources/download/pusdatin/infodatin/infodatin \%20reproduksi\%20remaja-ed.pdf Retrieved Oktober 29, 2016.

Nasrullah, M., Zakar, MZ. (2014). Child Marriage and Its Associations with Controlling Behaviors and Spousal Violence Against Adolescent and Young Women in Pakistan. Journal of Adolescent Health.

Park, Hee Sun (2000). "Relationships among attitudes and subjective norms: Testing the theory of reasoned action across cultures". Communication Studies: 162-175

Livia Sz. Oláh, Rudolf Richter and Irena E. Kotowska (2014). The new roles of men and women and implications for families and societies. Report. A project funded by European Union's Seventh Framework Programme under grant agreement no. 320116

Rumble, Lauren, Amber Peterman; Nadira Irdiana, Margaret Triyana and Emilie Minnick (2018). An empirical exploration of female child marriage determinants in Indonesia. BMC Public Health BMC series - open, inclusive and trusted 201818:407

Pender, N. J., Murdaugh, C. L., \& Parsons, M. A. (2001). Health Promotion in Nursing Practice. New Jersey: Pearson Education Inc.

Glanz K., Rimer B. K., Viswanath K. (2008). Health Behaviour and Health Education: Theory, Research and Practice. 4th Edition. San Francisco: Jossey-Bass Publisher.

Field, Erica, and Attila Ambrus. 2008. Early marriage, age of menarche, and female schooling attainment in Bangladesh. Journal of Political Economy, 116(5): 881-930

Hudelson, P.M (2004). Culture and quality: an anthropological perspective. International Journal for Quality in Health Care, 16(5), 1 October 2004, Pages 345-346, https://doi.org/10.1093/intqhe/mzh076

Juspin, L., Ridwan T., Zulkifli A. (2011).Studi Kasus Kebiasaan Pernikahan Usia Dini Pada Masyarakat Kecamatan Sanggalangi Kabupaten Tana Toraja. Makasar: Jurnal MKMI, 5(4). Oktober 2009.

Montazeri, S. Maryam Gharacheh, Nooredin Mohammadi, Javad Alaghband Rad, Hassan Eftekhar Ardabili (2016). Determinants of Early Marriage from Married Girls' Perspectives in Iranian Setting: A Qualitative Study. J Environ Public Health. 2016; 2016: 8615929. Published online 2016 Mar 30. doi: 10.1155/2016/8615929 